\title{
Evaluation of Phytochemical Constituents, Antibacterial Activities and Effect of Exudate of Pycanthus Angolensis Weld Warb (Myristicaceae) on Corneal Ulcers in Rabbits
}

\author{
DN Onwukaeme ${ }^{1}$ TB Ikuegbvweha ${ }^{1}$ and CC Asonye ${ }^{2}$ \\ ${ }^{1}$ Department of Pharmacognosy, Faculty of Pharmacy, University of Benin, Benin City, ${ }^{2}$ Department of Optometry, \\ Faculty of Life Sciences, University of Benin, Benin City, Nigeria
}

\begin{abstract}
Purpose: A 1: 1: 2 mixture of exudates of Anchomonas difformis, Cyrtrospherma senegalense and Pycanthus angolensis is claimed to be used for the treatment of corneal ulcers. The purpose of the study is to evaluate the phytochemical constituents, antibacterial activities and the effectiveness of a mixture of these exudates in the treatment of corneal ulcers as claimed in Traditional medicine practice.

Method: Fresh exudates were collected in different containers. They were reduced to dryness and each residue tested for phytochemical constituents. Exudates of $P$. angolensis was further tested for antimicrobial activities and its effect on chemical - induced corneal ulcers in rabbits.

Result: Only reducing sugars were detected in exudates of $A$. angolensis and $C$. senegalensis. Bioactive constituents detected in exudates of $P$. angolensis were the reducing sugars and phenolic compounds- tannins and flavonoids. This also showed antimicrobial activity against the organisms used. It healed the $\mathrm{NaOH}$ - induced corneal ulcers in rabbits within ten of days of treatment.

Conclusion: Exudates of P.angolensis contained bioactive constituents and exhibited antibacterial activity, and healed the corneal ulcers induced in rabbits. Its use in traditional practice for healing corneal ulcers is rational, even in the absence of exudates of $A$. angolensis and $C$. senegalensis.
\end{abstract}

Key words: Pycanthus angolensis, exudates, corneal ulcers, rabbits.

*Correspondence: Tel: +234-8033714849 E-mail: nkemmkparu@yahoo.com 


\section{INTRODUCTION}

Pycanthus angolenses Welw Warb (Myristicaceae) is also known as "African nutmeg or false nutmeg"1 The Nigerian Local names of the plant are, Abakang (Ibibio) Akwa mili (Ibo) Abora (Itsekiri), Akamo, Akujaadi (Yoruba), Nupe (Kpokgi), and Abaororo (Urhobo). Others are: Etena (Cameroon), and Loioka (Zaire) ${ }^{1}$ It is a forest tree of about 30.5 $\mathrm{m}$ high $2.45 \mathrm{~m}$ in girth. The bark is grey, longitudinally fissured, flaking in patches in old trees and exudes reddish coloured juice. It is widely used for ethnomedical purposes ${ }^{2}$ An infusion of the bark is reported to be effective in the treatment of leprosy ${ }^{3}$ and for purification of breast milk in Guinea. A terpenoid quinone with potential use in treatment of Type 2 diabetes was isolated from the plant ${ }^{4}$ Herbal medicine practioners in some parts of Delta State, Nigeria, claim that a 1: 1: 2 mixture of exudates of Anchomones difformis: Cyrtosperma senegalense: and Pycanthus angolensis respectively is used for treatment of corneal ulcers. (Personal communication with Tega Ikuegbvweha, the second-named author). This work was done to verify this claim.

\section{EXPERIMENTAL}

Plants exudates. Parts of Anchomonas difformis, and Pycanthus angolensis plants were collected from Ikpoba Hill, Benin City and Crytosperna senegalense was from Urhobo by the second named-author.

They were identified by Alhaji A. Abubakar a Taxonomist formally with the Department of Pharmacognosy, Faculty of Pharmacy, University of Benin. Exudates from each plant was collected into a separate bottle, reduced to dryness on the boiling water bath and the residue subjected to the tests.

Phytochemical tests: Phytochemical tests for bioactive constituents were carried out on portions of the residual material using standard phytochemical procedures ${ }^{5-8}$.

Fehling's test for reducing sugars (in glycosides): The residue was re-dissolved in water on the water bath. To $2 \mathrm{ml}$ of the solution, in the test tube was added, $1 \mathrm{ml}$ each of Fehling's solutions $A$ and $B$. The mixture was shaken and heated in a water bath for $10 \mathrm{~min}$. The colour obtained was recorded. A brick-red precipitate indicates reducing sugar.

Frothing test for saponins: Water extract was obtained by boiling on the water bath. The extract was transferred into a test tube and shaken vigorously then was left to stand for 10 mins and the result noted. A thick persistent froth indicates saponins.

Borntrager's test for anthraquinone derivatives: Chloroform extract of the material was obtained by boiling on the water bath. To $2 \mathrm{mls}$ of this extract, $1 \mathrm{ml}$ of dilute (10\%) ammonia was added and the mixture was shaken. Any colour change was recorded. A pink-red colour in the ammoniacal (lower) layer shows anthracene derivatives.

Test for Flavonoids Water extract of the sample was reduced to dryness on the boiling water bath. The residue was treated with dil. $\mathrm{NaOH}$, followed by addition of dilute $\mathrm{HCl}$, solubility and colour were noted. A yellow solution with $\mathrm{NaOH}$, which turns colourless with dil $\mathrm{HCl}$ confirms flavonoids.

Ferric chloride solution test for tannins: Water extract was treated with $15 \%$ ferric chloride test solution. The resultant colour was noted. A blue colour indicates condensed tannins, a green colour indicated hydrolysable tannins.

Colour tests for alkaloids: $500 \mathrm{mg}$ of plant material was extracted with $500 \mathrm{mls}$ of methanol for 20 minutes, on a water bath The extract was then filtered off and allowed to cool. This extract was dispensed in $2 \mathrm{ml}$ of portions into four different test tubes. Either the Dragendorff's or Hager's or Mayer's or Wagner's alkaloidal reagent was added to each tube and the presence or absence of colours of any precipitates were noted in each test tube.

Keller-Kiliani test (for de-oxy sugars in cardiac glycosides): Methanol extract was obtained and the extract reduced to dryness. $50 \mathrm{mg}$ of this was dissolved in $2 \mathrm{ml}$ chloroform. $\mathrm{H}_{2} \mathrm{SO}_{4}$ was added to form a layer and the colour at interphase recorded. Brown ring at interphase is characteristic of deoxysugars in cardenolides. The results showed the presence of only reducing sugars in $A$. difformis and $C$. senegalense but showed that $P$. angolensis 
Onwukaeme et al

Table 1: Phytochemical constituents of exudates of Pycanthus angolensis

\begin{tabular}{|c|c|c|}
\hline Test & Observation & Inference \\
\hline $\begin{array}{l}\text { Test for reducing sugars } \\
\text { in glycosides (Fehling's } \\
\text { solutions test) }\end{array}$ & $\begin{array}{l}\text { Blue colour of Fehling's } \\
\text { solutions } \\
\text { turned brick red ppt. }\end{array}$ & Presence of reducing sugar \\
\hline Frothing test for & Only bubbles seen. No & \\
\hline $\begin{array}{l}\text { Saponins } \\
\text { Borntrager's reagent test for } \\
\text { anthracene derivatives }\end{array}$ & $\begin{array}{l}\text { frothing } \\
\text { Same shade of pink as the } \\
\text { exudates }\end{array}$ & $\begin{array}{l}\text { Absence of Saponins } \\
\text { Absence of Anthracene } \\
\text { derivatives }\end{array}$ \\
\hline $\begin{array}{l}\text { Keller Kiliani test for } \\
\text { deoxysugars in cardiac } \\
\text { glycosides }\end{array}$ & No brown ring colour & $\begin{array}{l}\text { Absence of deoxysugars, } \\
\text { no cardiac glycosides. }\end{array}$ \\
\hline $\mathrm{FeCL}_{3}$ solution test for Tannins & Blue-black ppt & $\begin{array}{l}\text { Hydrolysable } \\
\text { Tannins present }\end{array}$ \\
\hline $\begin{array}{l}\text { Test for flavonoids } \\
\mathrm{NaOH} \text { Test }\end{array}$ & $\begin{array}{l}\text { Flavonoids dissolved giving } \\
\text { yellow colour. } \\
\text { solution turns colorless with }\end{array}$ & Flavonoids present. \\
\hline $\begin{array}{l}\text { HCl test } \\
\text { Tests with Dragendorff's, } \\
\text { Hager's,Mayer's, Wagner's } \\
\text { alkaloidal Reagents for } \\
\text { Alkaloids }\end{array}$ & $\begin{array}{l}\mathrm{HCl} \\
\text { No Coloured ppt with any } \\
\text { reagent }\end{array}$ & Absence of Alkaloids \\
\hline
\end{tabular}

Table 2: Antibacterial activities of exudates of $P$. angolensis and reference drugs on test bacterial organisms

\begin{tabular}{rcccc}
\hline $\begin{array}{l}\text { Treatment } \\
\text { (ug/disc) }\end{array}$ & \multicolumn{4}{c}{ Organisms and diameters of Zones of inhibition (mm) } \\
\hline Exudates: 50 & S. aureus & Strep. pyrogens & E. coli & P. auregenosa \\
& 8.2 & 10.4 & 10.5 & 6.1 \\
100 & 12.6 & 16.6 & 14.3 & 7.5 \\
250 & 19.4 & 21.5 & 15.2 & 10.6 \\
Ampicillin 20 & 25.8 & 28.8 & 18.4 & 12.2 \\
Gentamicin 20 & 18.3 & 23.7 & 27.9 & 14.1 \\
\hline
\end{tabular}

Table 3: Effects of exudates of $P$. angolensis on chemical-induced corneal ulcers in rabbits

\begin{tabular}{lll}
\hline Parameter & $\begin{array}{c}\text { Ocular state of ulcerated and } \begin{array}{c}\text { treated rabbits } \\
\mathbf{1}^{\text {st }} \text { Day }\end{array} \\
\text { Say }\end{array}$ \\
Status of eyelid & Badly inflamed & No Inflammation \\
Lacrimation & Very severe & Normal \\
Discharge & Nil & Nil \\
Corneal Tissue & Badly ulcerated & Healed \\
\hline
\end{tabular}




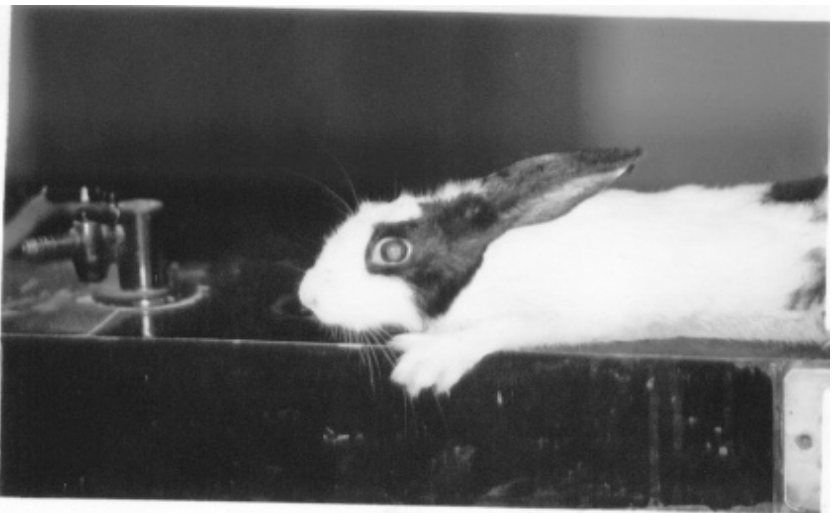

A

Normal left eye rabbit

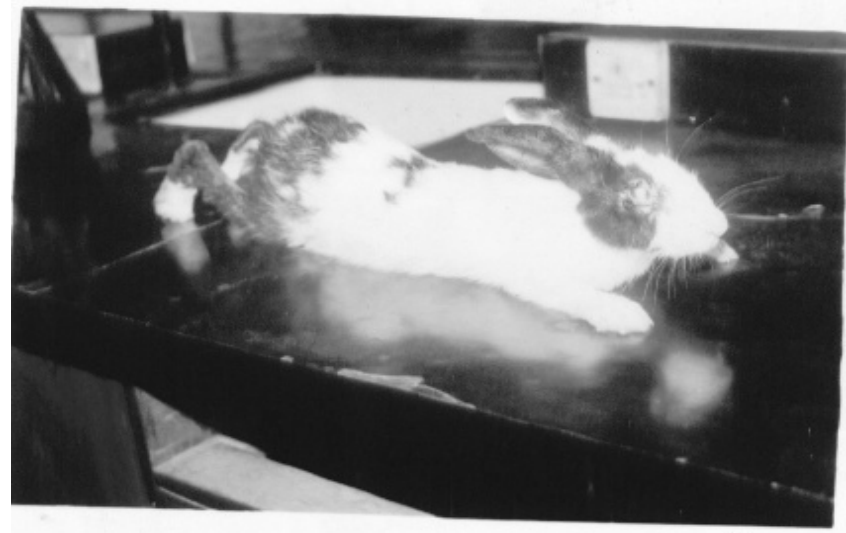

$\mathrm{B}$

Right eye on $1^{\text {st }}$ day of ulcer induction

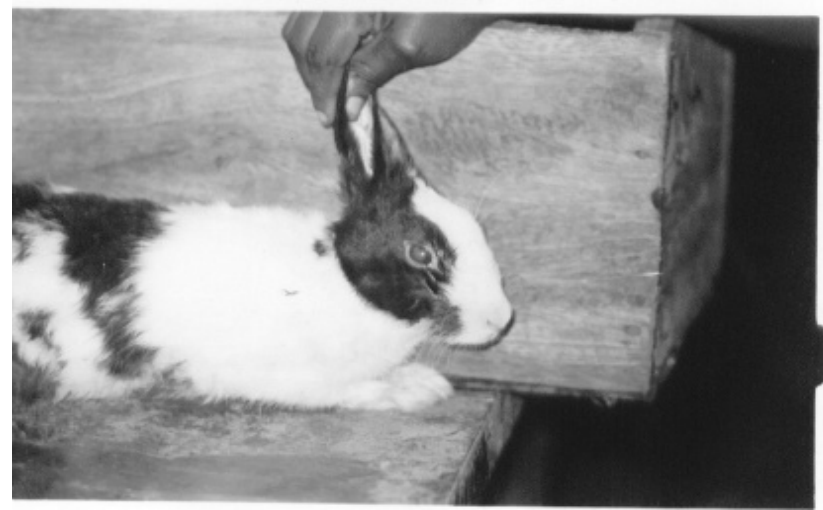

Right eye of $B$ on $10^{\text {th }}$ day of treatment with exudates

Fig 1: Result of Treatment of induced corneal ulcers with $P$. angolensis exudates 
contained reducing sugars, as well as tannins and flavonoid glycosides. These are constituents that could have biological activity, hence the biological tests were carried out on the $P$. angolensis exudates only.

Test Organisms: Standard Laboratory strains of the organisms were obtained from the University of Benin Teaching Hospital and sub cultured in the Laboratory of Pharmaceutical Microbiology, University of Benin. The organisms used were Escherichia coli (Gram-negative), Pseudomonas aeruginosa (Gram-negative) Staphylococcus aureus (Gram-positive) and Streptococcus pyrogens (Gram-positive). The bacterial cultures were maintained on nutrient agar (Oxoid Ltd). Prior to use, they were sub-cultured into nutrient broth and incubated overnight at $37{ }^{\circ} \mathrm{C}$.

\section{Antibacterial tests}

The activities of exudates on the organisms were evaluated using the paper disc diffusion method (9). $100 \mathrm{mg}$ of dried residue was redissolved in 10 $\mathrm{ml}$ normal saline and from this stock solution volumes equivalent to 50,100 and $250 \mu \mathrm{g} /$ disc were spotted on antibiotic sterile assay paper discs (Whatman No. 1 (0.6cm diameter). A blank containing normal saline and another containing $20 \mu \mathrm{g} / \mathrm{disc}$ of a particular reference drug (Ampicillin or gentamicin) were also set up. The discs were allowed to air-dry and then placed on pre-sterilized agar plates (10 $\mathrm{cm}$ diameter) containing $10 \mathrm{ml}$ of Agar Muller Hinton 3.5\% medium, and spread with $10 \mu \mathrm{l}$ of a standardized inoculum $\left(5 \times 10^{5}\right.$ cells $\left./ \mathrm{ml}\right)$ of the test bacterium. Plates were incubated for $24 \mathrm{hr}$. at $37^{\circ} \mathrm{C}$ and zones of inhibition measured $(\mathrm{mm})$. Experiments were set up in four replicates. The results are presented in Table 2.

Effect of exudates on corneal ulcers in rabbits.

Animals: Rabbits, 300-450 g body weight were bought from Aduwawa in Benin City. They were maintained on potato leaves, elephant grass and mature unripe pawpaw fruits and water for a period of 8 weeks for them to acclimatize.

Animal Care: They were de-wormed by $0.1 \mathrm{ml}$ invome Super ${ }^{R}$ subcutaneously (sc) administered. Also to improve their immunity and check infection and stress, keproceryl and vitalite were given orally.

Induction of ulcer. Animals were anaesthetized with ketamin injection (sc) 2 drops of $4 \%$
Novesea tropical anesthetic agent instilled into the cornea of right eyes of 2 rabbits, (A) followed 20 mins later with 2 drops of $1 \mathrm{M}$ solution of $\mathrm{NaOH}$ instilled into the eyes. The 2 left eyes (B) were left as control. The 2 animals showed ulcerated cornea $(A)$ and so were used for the test. The dried residue was re-dissolved in normal saline to make a stock of $2 \% \mathrm{w} / \mathrm{v}$ from this, 2 drops were daily instilled into the right ulcerated eyes (A). The extract was administered 3 times daily for nine consecutive days following induction. Animals were allowed free food and water. During this period, observations were made for any signs of toxicity, infection and discharge, status of the ulcerated cornea, any healing.

Photograph of the ulcerated, non-ulcerated and treated eyes were taken on the $1^{\text {st }}$ day of treatment and on the and $10^{\text {th }}$ day of experimentation. The photographs are enclosed. (Fig1)

\section{RESULTS AND DISCUSSION}

Exudates of $A$. difformis and $C$. senegalense, contained only reducing sugars. Exudate of $P$. angolensis contained reducing sugars, flavonoids and tannins. In the antimicrobial test, (Table 2) $50 \mu \mathrm{g} / \mathrm{ml}$ exudate had least activity against all the organisms. It was most active against Strep pyrogens. Though $250 \mu \mathrm{g} / \mathrm{ml}$ showed significant activity on the organisms, these were less than those of the reference drugs. The induced ulcers were healed within nine days (Fig 1). There was no sign of toxicity in the animals that received the exudates. Phenolic compounds are generally noted for their antimicrobial activities. ${ }^{5,8} \quad$ Specifically, antimicrobial activities of tannins and flavonoids of Allium cepa ${ }^{10}$ and Thymus serphylum ${ }^{11}$ have been reported. These phenolic constituents present in the exudates could then be responsible for its antibacterial effect as noted in this work. In addition, tannins act externally as water proof to the external layers of the exposed tissue since they precipitate proteins, thus protecting the underlying layers. They also have vasoconstriction effect on small superficial or exposed vessels. By limiting fluid losses and by preventing external aggressions, tannins enhance tissue regeneration in case of 
superficial wounds or burns $s^{8,10}$. This further strengthens the healing activity of the exudates. Thus the healing effect of exudates could also be attributed to the above actions of Flavonoids and tannins.

\section{CONCLUSION}

This work has identified the phytochemical constituents in exudates of $A$. difformis, $C$. senegalense and $P$. angolensis. $A$ the antibacterial activities of exudates of $P$. angolensis, though less than the activities of the reference drugs, ampicillin and gentamicin, has been demonstrated. The $P$. angolensis exudates alone was active, it healed corneal ulcers within nine days of treatment, in contrast to the claim that the mixture of exudates of the three plant materials exerts the effect.

\section{REFERENCES}

1. Bep O. Medicinal Plants in Nigeria. Published as a Private Edn The Nigerian College of Arts, Science and Technology Ibadan. 1960: 3-20.

2. Akendengue B and Louis AM. Medicinal Plants used by the Masanga People in Gabon. J. Ethnopharmacol 1994: 41 193-200.

3. Vasileva, B. Medicinal Plants of Guinea. Conakry Republique de Guinea Masco USSA. Moscow University 1969: p 1.

4. Jeamecheung LJ, Yevish EM, Clarke JP, Tsai J, Priscilla Lopresca, J
Ubillas RP, Fort DM. Hector RF, King SR, Mendez CD, Gerald DJ, Hector RF, King SR, Mendez CD, Jolad SD, Rewoven GM. Novel type quiinones isolated from Pycanthus angolensis of potential utility in the treatment of Type 2 diabetes. $J$. Pharmacology and Therapeutics, 1999; 2: 529-534.

5. Bruneton J. Pharmacognosy, Phytochemiistry and Medicinal Plants. Intercept Ltd Londers, New York. $2^{\text {nd }}$ Edn. p. 386.

6. Sofowora A. Medicinal Plants and Traditional Medicine in Africa. John Wiley and Sons Ltd. Chichester. 1982, pp 142-145.

7. Harborne JB. Phytochemical Method: A guide to Modern Techniques of Plants Analysis. $2^{\text {nd }}$ Edn. Chapman and Hall New York. 1983.

8. Evans WC. Trease and Evans Pharmacognosy $13^{\text {th }}$ Edn E.LBS with Bailliere Tindall. 1989 pp. 388, 480, 502, 535, 546.

9. Bauer AW, Kirby WMM, Sherris JC, Turck M. Antibiotic susceptibility testing by a standardized single disk method. Am J.Clin Pathol. 1966; 45: 493-496.

10. Izo AA, Cario GD, Briscards D. Biological screening of Italian medicinal plants for antibacterial activity. Phytother. Res. 1995. 9: 281-286

11. Janssen AM, Scheffer JJC, Baerheim SA. Antimicrobial activity of essential oils. A 1996- 1998 Literature Review. Plants Med. 1987. 53. 395-398. 